\title{
Valorization and characterization of CCRs of the Jerada thermal power plant in the northeast of Morocco
}

\author{
Youssef REGAD ${ }^{\# 1}$, Bachir ELKIHEL ${ }^{\# 2}$, Fabienne DELAUNOIS ${ }^{* 3}$ \\ \# Team Industrial Engineering, Maintenance and Mechanical Production, Mohamed $1{ }^{\text {st }}$ University, \\ National School of Applied Sciences of Oujda, BP 669, 60000 Oujda, Morocco. \\ ${ }^{1}$ youssefregad@gmail.com, 2 belkihel@yahoo.fr \\ * Department of Metallurgy, University of Mons Polytechnic Faculty, \\ Street of the Epergne 567000 Mons, Belgium. \\ ${ }^{2}$ fabienne.delaunois@umons.ac.be
}

\begin{abstract}
The thermal power plants are globally criticized for generating large amount of solid wastes often with a potential environmental impact. The main objective of this study is characterized the CCRs (Coal Combustion Residues) produced by the thermal power plant in the East region of Morocco (Jerada city). On other hand, in order to use this CCRs (fly ash and bottom ash) effectively, it is necessary to study the raw material of which they are trained in all their aspects and to check their behavior in the various employment possibilities.
\end{abstract}

For this purpose, mechanical compressive test on $10 \times 10 \times 10 \mathrm{~cm}^{3}$ of mortar specimens and chemical test of $\mathrm{X}$-ray on CCRs are performed. We did work on the use of CCRs as an addition in Portland cement. Firstly, compressive tests and chemical requirements were used to evaluate the pozzolanic activity index according to ASTM C618 which is about $89,75 \%$. Indeed, the results of an experimental plan, on compressive strength of the new by-product $(10 \%$ CCRs and $90 \%$ cement), gave a good response of our plan, it's about 24,20 MPa. Secondly, we have added this new by-product with the clay to produce the fired compressed bricks according to a new experimental plan, where we found that the most response of the compressive strength equal to 3,12 MPa, in which a minimum volume of water of $581 \mathrm{~cm}^{3}$ and a minimum quantity of clay of $50 \%$ (by total mass of $1 \mathrm{~kg}$ ), were used.

In order to valorize these residues, our results show a good correlation with the ASTM standard and we can use this by-products in bricks manufacture.

Keyword-Fly Ash, Bottom Ash, Valorization, Waste, Coal, CCRs, Pozzolanic, $\mathrm{CO}_{2}$, by-product, Boiler.

\section{INTRODUCTION}

According to the European Agency for the Environment [1], all sectors of the industry, all commercial activities let a print on the environment because they use the energy or raw materials; produce the waste or sewages that we found in then in the natural habitat or urban. Such impacts can occur in the local level, crossborder level or world level, and to include some implications for health. They vary according to the phases of the product lifecycle and depending on the used raw materials, the product designs, the technology and research applied at the time of its manufacture, of the processes of transformation and manufacturing used, of the type of product created, of the packing of the product, of its way of distribution to the consumers and, finally, of its ultimate fate. It can be eliminated, reused or recycled.

Coal Combustion Residues (CCRs), also known as Coal Combustion Products, are the wastes from thermal power stations. These include fly ash (FA), bottom ash (BA), boiler slag (BS), fluidized bed combustion ash (FBCA), flue gas desulfurization (FGD). Current worldwide annual production of coal combustion products is estimated to exceed 600 million tonnes, being highly influenced by China's explosives trends and lack of data for the underdeveloped areas of that Country [2]. Estimation about production and reutilization of CCRs by major producer countries is reported in Table I [3].

Recycling, being one of the strategies in minimisation of waste, offers three benefits: (i) reduce the demand upon new resources, (ii) cut down on transport and production energy costs and (iii) use waste which would otherwise be lost to landfill sites [10]. The reutilization and/or recycle of such by-products has been studied for decades in many areas and research and proposals are still developed in several countries (Table II), but with remarkable differences as far as added-value is concerned. 
TABLE I Production and utilization of CCRs in major producer countries.

\begin{tabular}{|l|c|c|c|c|c|}
\hline Country & $\begin{array}{c}\text { CCRs production } \\
\text { (Mt) }\end{array}$ & $\begin{array}{c}\text { CCRs utilization } \\
\text { (Mt) }\end{array}$ & $\begin{array}{c}\text { Utilization rate } \\
\text { (\%) }\end{array}$ & Year & References \\
\hline USA & 117,289 & 61,1 & 52,05 & 2015 & {$[4]$} \\
China & 350 & $203^{\mathrm{a}}$ & 58,0 & 2010 & {$[2]$} \\
India & 105 & 28,3 & 27,0 & 2005 & {$[5]$} \\
EU15 & 48,327 & 47,749 & 91,0 & 2010 & {$[6]$} \\
Australia & 12,1 & $\mathrm{~b}$ & 40,0 & 2015 & {$[7]$} \\
Japan & 11 & 4,8 & 97,2 & 2006 & {$[8]$} \\
Canada & 6,846 & 10,6 & 26,0 & 2010 & {$[9]$} \\
Total & $\mathbf{6 5 0 , 5 6 2}$ & 1,761 & $\mathbf{5 4 , 9 2}$ & & \\
& & $\mathbf{3 5 7 , 3 1}$ & & & \\
\hline
\end{tabular}

${ }^{a}$ Estimation and extrapolation from available data.

${ }^{\mathrm{b}}$ Datum includes also Reclamation and Restoration utilization. Without including this, the CCRs utilization is $25,290 \mathrm{Mt}$ with an average utilization rate of $52 \%$.

TABLE II Particular reuses and recycles of CCRs in different countries.

\begin{tabular}{|l|l|l|l|}
\hline \multicolumn{1}{|c|}{ Country } & \multicolumn{1}{|c|}{ CCR type } & \multicolumn{1}{c|}{ Application } & References \\
\hline India & CCRs & Various brick productions & {$[4]$} \\
Japan & Ashes & Development of artificial Z-sand for Civil Engineering & {$[11]$} \\
USA & FA & Non-fired bricks & {$[12]$} \\
Australia & FA & $1000^{\circ}$ fired bricks & {$[13]$} \\
USA & FA & Fired bricks & {$[14]$} \\
Taiwan & FA & Fired and non-fired bricks using ashes mixed with & {$[15]$} \\
Turkey & FA & pond sludge & {$[16]$} \\
Russia & Ashes \& mining & Fired bricks & {$[17]$} \\
Turkey & wastes & Construction ceramic materials & {$[18]$} \\
USA & FA, BA, furnace slag & Cement and fine sand replacement in concrete & {$[19]$} \\
Sweden & BA \& FA & Enhancement of rammed earth constructions & {$[20]$} \\
Spain & BA & Light fill material & {$[21]$} \\
Netherlands & FA \& slag & Light weight aggregates & {$[22]$} \\
& FA & Bricks and concrete & \\
\hline
\end{tabular}

From where the valorization of the waste is a strategic gait for all country of the world, it is about the transformation of an unusable residual to a wealth. The valorization of CCRs is indeed very common in the cement industry as raw material in the production of the cement clinker, interground with the clinker, or blended with the finished cement [4], [23].

This procedure is profitable for our environment and witch has remarkable advantages. For our study, the objective is to valorize the solid residues generated by the coal power plant of Jerada city and to find efficient uses for this material that causes some problems for the thermal power plant in term of cost of evacuation as well as the environmental level.

At the time of this study a physicochemical characterization has been made to define the material, then several uses have been developed and have been tested.

\section{DEFINITION OF THE WASTE}

To the origin of all particular measure aiming the waste, there is the hypothesis that the very notion of waste can be defined. However, most authors agree to say that at the present, it's doesn't exists a satisfactory definition for the waste [24], [25], [26]. Indeed, the notion of waste can aim objects of nature and different functions.

To avoid the misunderstandings, the different actors implied in the management of the environment tempted to give a definition to the word "waste". There are actually several definitions that correspond to a particular objective. Every definition aims for actor's group to establish the set of the objects that should be the subject of a particular behavior or a particular attention, but it is lastly the legal definition that should act as reference [27].

\section{A. Authorized Approach}

For the legislator, it was above all about regulating the treatment of the waste as while prohibiting the reject in the environment or the resale within sight from escaping the legal obligations. It was necessary to be able to define exact manner what entered in the setting of the law therefore. 
The French law of July 15, 1975 defines the waste as « all residual of a production process, transformation or use, all substance, material, product or generally all good abandoned piece of furniture or that its possessor destines neglected ».

\section{B. Environmental Approach}

Of the environment viewpoint, a waste constitutes a threat from the moment where we consider a contact with the environment. This contact can be direct or the result of a treatment. Historically, as a result of the predominance of the technical burying sector for many years, we consider this contact as unavoidable. Several definitions put thus forward the composition of the waste as identification criterion (as the European guideline indicates it from March 18, 1991). This approach can conduct to consider by-products of nature dangerous or containing of the pollutants as waste independently of their value or their possible reuse.

\section{Economic approach}

On the economic plan, a waste is a matter or an object whose economic value is hopeless or negative for its holder to one moment and in a given place [28]. This definition excludes a good part of the recyclable waste that possesses an economic value, even weak. Some companies can be tempted thus to make pass some waste for by-products to subtract them to the law.

\section{Functional approach}

Finally, we can choose to adopt for the waste a « functional » approach illustrated in Fig. 1. In this case, the waste is considered like a flux of materiel coming from a functional unit, this one representing an activity or a set of activity.

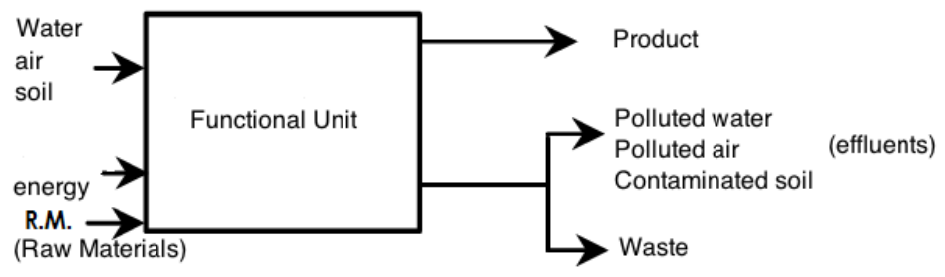

Fig. 1. Functional definition of waste

The residues are themselves compound of the unsought results. Some authors speak about desirable outputs and undesirable outputs [29]. Among these unsought results, we find the natural environment elements transformed by the activity. Then we are talking about the effluents, the nuisances (noise), the energy (energizing losses) and the waste that corresponds to all the material elements unassimilable directly with the natural environment elements.

It is immediately apparent that the boundary between waste and effluent can be quite arbitrary. Indeed it depends on the limits that we choose it beyond which the flux cannot be more assimilated to a natural environment element. In general, the operations associated to the flux which will determine if it is about a waste or an effluent. We speak of effluent in the case of a reject in continuous after a possible treatment, of waste in the case of a discontinuous reject. This distinction between waste and effluent can prove to be on the convenient plan insofar as the authorized constraints are not the same for the two types of rejects. However an effluent can be transformed into waste at the end of a treatment decision. Inversely, the treatment of a waste almost always results in the discharge of an effluent that constitutes, in fact, a part of the initial waste.

In this work, we will adopt the functional definition of waste by extending it to liquid and gaseous effluents in the last part concerning internal treatment. We now need to clarify the notion of special industrial waste. To this end, we will place it among the different categories that form the typology of waste.

\section{III.THE WASTE TYPOLOGY}

A first approaches brings us, of course, to distinguish the waste according to their physical nature: solids, liquids, gaseous. Even though many reasoning are applicable to the three categories of waste, we will treat the case of the solids and gaseous waste, that is often the subject of special treatments and they are not aimed explicitly by numerous authorized arrangements concerning the waste.

It is current to distinguish the waste following their origin:

- Urban waste that regroups the garbage and the waste of the townships;

- Industrial waste (our case);

- Agricultural waste. 
The special industrial waste in which we are interested represents in Morocco a big tonnage in the last years. A classification way involves the position of the waste in the treatment process, as illustrated in Fig. 2. We then distinguish waste:

- Primary, waste before treatment,

- Intermediate, it is the waste resulting from the treatment of a waste or of an effluent,

- Ultimate, last link of the treatment chain.

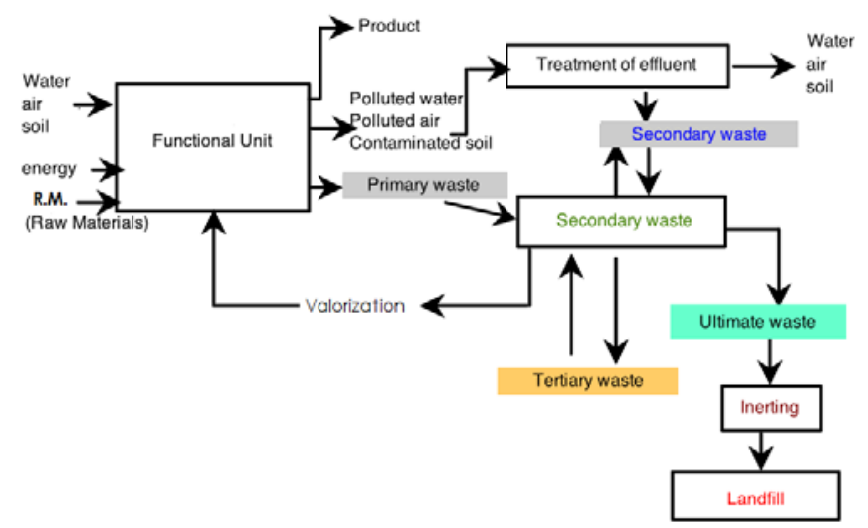

Fig. 2. The waste lifecycle

The ultimate waste constitutes an important reference for the treatment. Indeed, according to the laws in vigor, from 2002, only the ultimate wastes are admitted in the storage sites.

\section{IV.WORKING PRINCIPLE OF A THERMAL POWER PLANT}

The production of the electrical energy in a thermal power plant passes through a succession of energy transformation steps, Fig. 3, ranging from chemical, calorific, mechanical and then electrical energy [30].

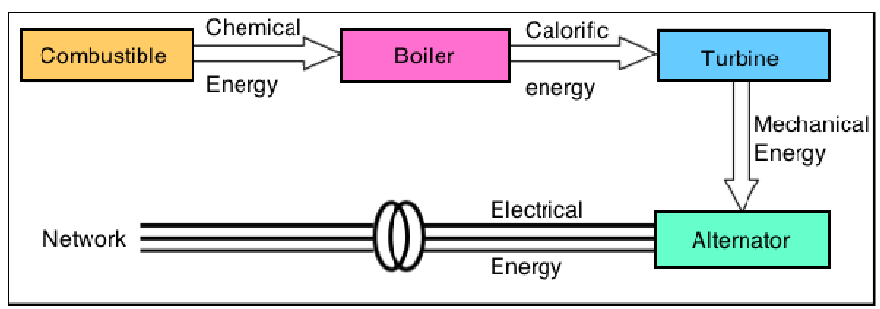

Fig. 3. Production steps of the electrical energy at the Jerada TPP

Indeed, because of exothermic reaction of the combustible, within the boiler, the chemical energy is converted into calorific; this last is recovered by water to be transformed into steam. Having reached approximately a temperature of $540{ }^{\circ} \mathrm{C}$ and a pressure of $90 \mathrm{bar}$, the steam is used to make the turbine rotates at $3000 \mathrm{rpm}$, which generates a mechanical energy giving a rotation movement for the alternator. So the alternator converted this mechanical energy into electric energy. The Fig. 3 summarizes these energy transformation steps.

The combustion, in the boiler, is effected by the following solids combustibles: the anthracite, the coal steam (it is an imported coal) and the mixture $80 / 20$ of coal steam and Petcock. Indeed, an analysis on the three combustibles used in the TPP with the aim to determine the chemical characteristics of every type, the Fig. 4 shows us that every combustible has its own residual with different characteristics. Hence the study of the combustion of every type of the coal by the establishment of a thermal balance sheet and by the analysis of the distribution of heat in the boiler, it is a project for the next research works, may be necessary to determine the pathway of the residue reuse according to the functional approach discussed in Section 2-D. 


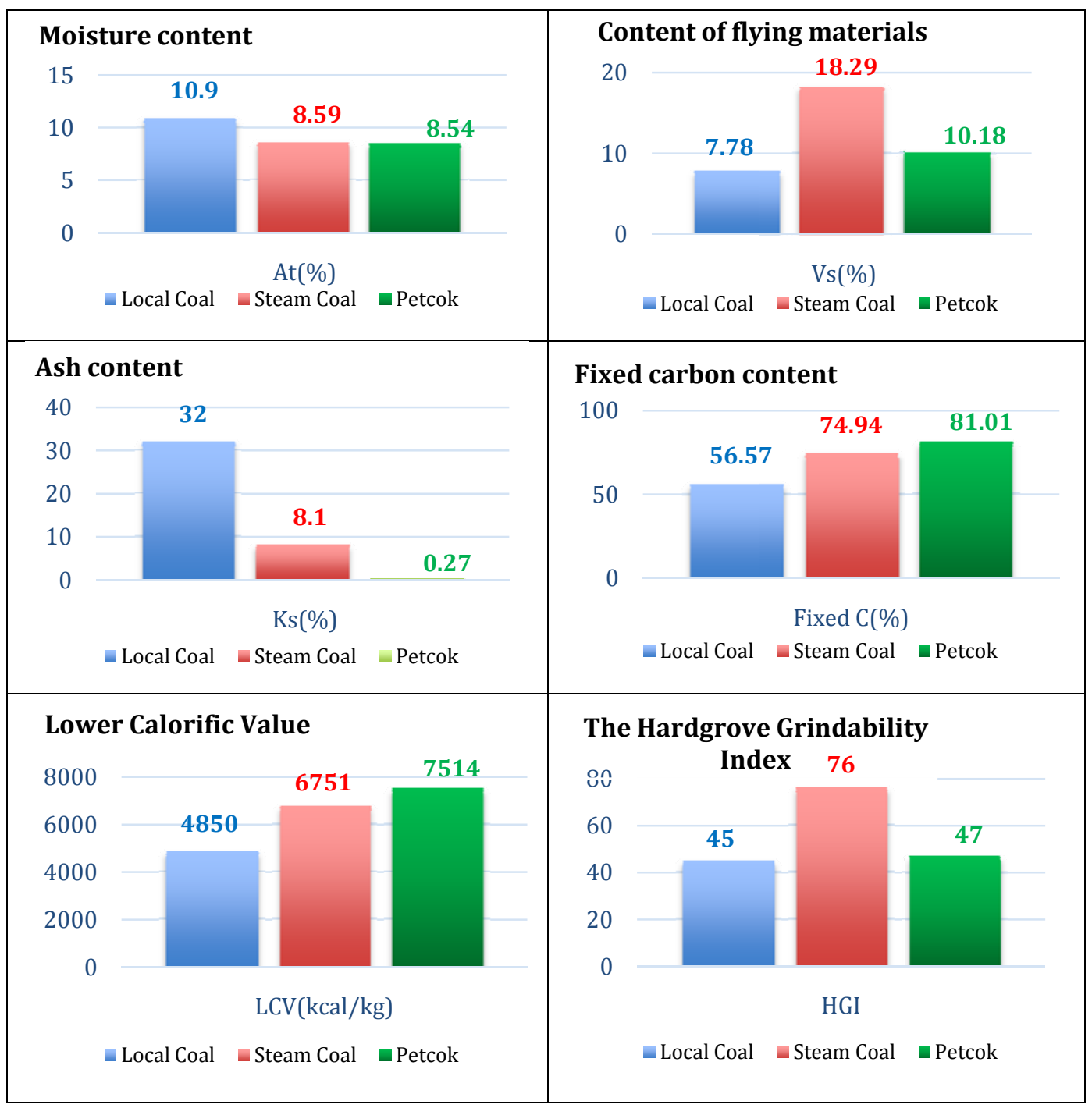

Fig. 4. Coals characteristics interveners in the combustion of Jerada TPP.

\section{Preliminary study Of The bottom ash (SOlid Waste):}

The bottom ash is a residual resulting from the combustion of coal, collected in the ashtrays, it takes on the appearance of dough carried to the red that is due to the silica melted to a temperature of $1450{ }^{\circ} \mathrm{C}$, the best is coal presenting the less bottom ash [30].

These bottom ash, illustrated in the Fig. 5, are composed of vitrified fragments with sharp edges whose dimensions vary in large measures according to the type of coal.

A. Properties of the bottom ash

- Very abrasive material,

- Flow of 1 ton per hour,

- Maximal granulometry at the exit of the boiler $\approx 350 \mathrm{~mm}$,

- Density of $\approx 1.967 \mathrm{~g} / 1$. 

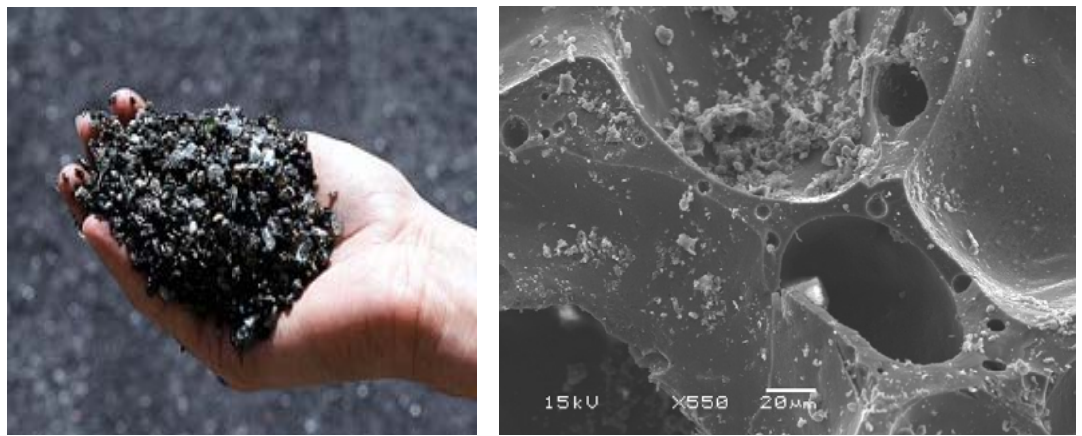

Fig. 5. Form and SEM (Scanning Electron Microscopy) image of sampled BA [3].

\section{B. Preliminary study of the fly ash}

The fly ashes are composed of the spheroidal particles very fine, their diameter being in the order of 35 microns, see Fig. 8, the finest are sucked by the emission ventilators, the biggest are collected in the dust collectors for the tranches number 1 and 2 , and for the $3^{\text {rd }}$ tranche they are collected in the electrostatic filter then evacuated to the soot channel.

\section{Properties of the fly ash}

- Very abrasive and dusty material,

- Flow of 4 ton per hour,

- Maximal granulometry at the exit of the boiler $\approx 35 \mu \mathrm{mm}$,

- Density of $\approx 1.967 \mathrm{~g} / \mathrm{l}$.

\section{The bottom ash of Jerada TPP Morocco}

The bottom ash are evacuated by trucks towards public dump sites, Fig. 6 and Fig. 7, generally these sites occupy several hectares and make them unusable nor for agriculture or for the habitat, these sites containing thousands of tons of bottom ash, present a strong concentration of the toxic heavy metals that can affect the living being, soil and even the groundwater.

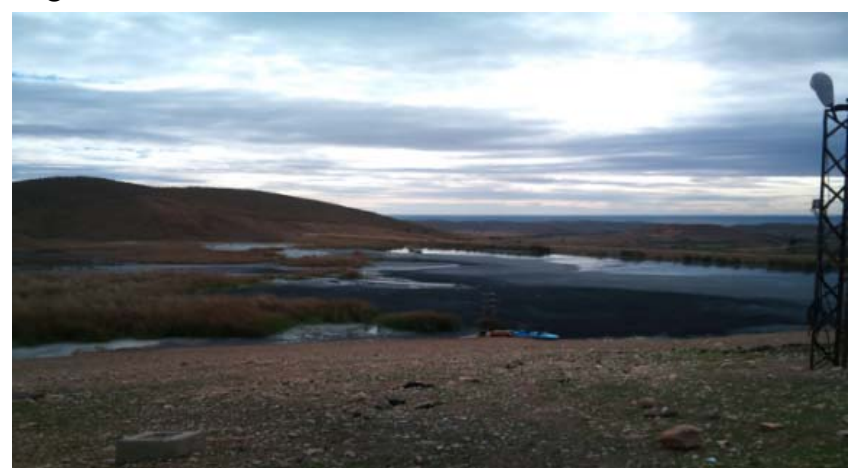

Fig. 6. Example of a public dump site of CCRs of Jerada.

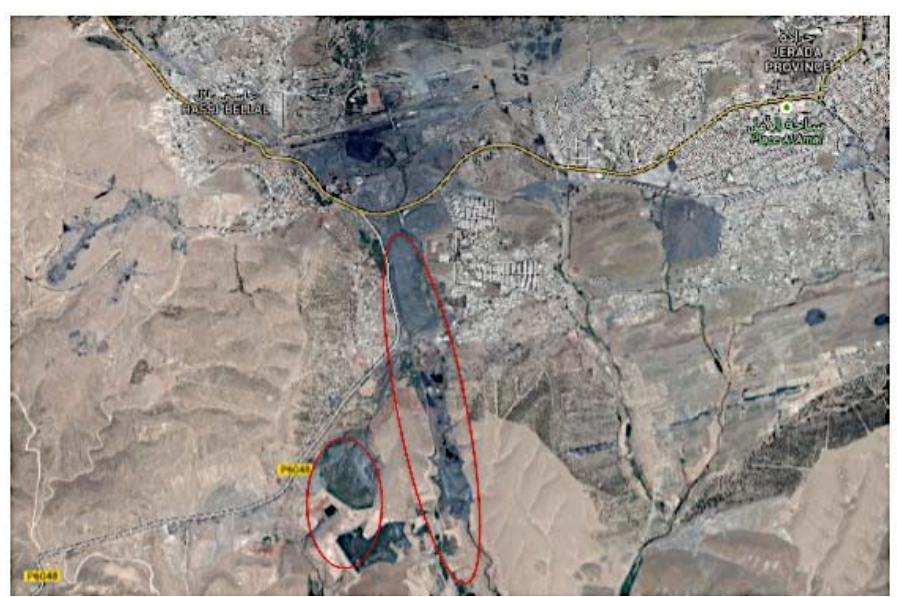

Fig. 7. Satellite view of one of the waste dump site (Source: Google Map). 

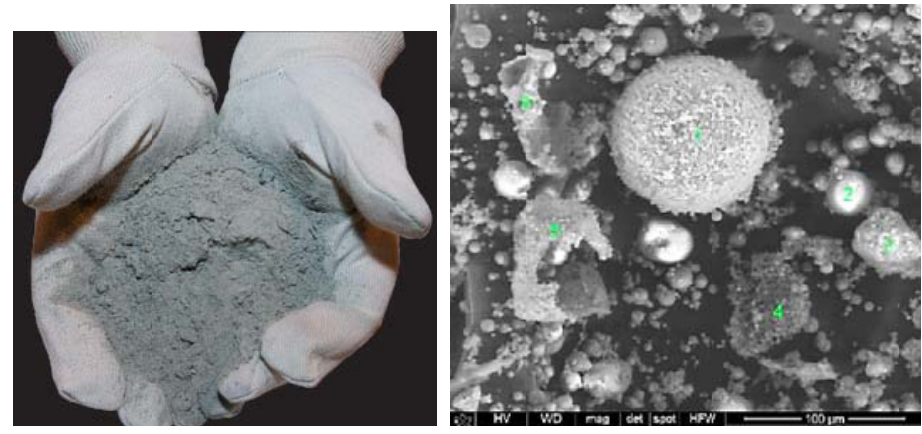

Fig. 8. Form and SEM image for fly ash sample, at 1000x magnification [31].

\section{VI.PHYSICAL CHARACTERISTICS OF THE BOTTOM ASH OF COAL}

The coal bottom ash is partially a vitrified coarse product composed of incombustible minerals which is present in the coal. The grain size distribution is similar to that of sandy gravel with a particularly low grain density which varies between 1,8 and $2,2 \mathrm{t} / \mathrm{m}^{3}$ and an apparent density about 0.7 to $0.9 \mathrm{t} / \mathrm{m}^{3}$ and capable to reach 1,2 t/m $\mathrm{m}^{3}$ after compaction, as shown in Fig. 5. The hydraulic conductivity (permeability) of the bottom ash, which varies between $10^{-2}$ and $10^{-5} \mathrm{~m} / \mathrm{s}$, is in the same size orders that those gotten for the natural materials with the same repartition granulometric. It is very porous with a porosity ranging from $30 \%$ to $55 \%$ [4], for more parameters of BA; we can see the Table III.

TABLE III Summary of the physical characteristics of BA [4], [23], [32], [33].

\begin{tabular}{|l|l|}
\hline \multicolumn{1}{|c|}{ Parameters } & \multicolumn{1}{c|}{ Values } \\
\hline Color & Gray to black \\
\hline Form & Near spherical \\
\hline Granulometry & Gravel to Sand \\
\hline Specific density & 2,2 to $2,8 \mathrm{t} / \mathrm{m}^{3}$ \\
\hline Apparent density & 0,7 to $1,6 \mathrm{t} / \mathrm{m}^{3}$ \\
\hline Porosity & $30 \%$ to $55 \%$ \\
\hline Permeability & $35 \%$ to $55 \%$ \\
\hline Plasticity & Not plastic \\
\hline Cohesion & Negligible \\
\hline Young's modulus & $30 \mathrm{MPa}$ to $55 \mathrm{MPa}$ \\
\hline friction angle & $35^{\circ}$ \\
\hline
\end{tabular}

\section{CHEMICAL AND MINERALOGICAL PROPERTIES OF COAL BOTTOM ASH}

The chemical characteristics of the bottom ash vary according to the type, to the source and the finesse of the combustible of which they come and to the conditions of exploitation of the coal power plant. In general, the CCRs (Coal Combustion Residues) are characterized by a high fraction of silicon oxide $\left(\mathrm{SiO}_{2}\right)$, of aluminum oxide $\left(\mathrm{Al}_{2} \mathrm{O}_{3}\right)$ and of iron oxide $\left(\mathrm{Fe}_{2} \mathrm{O}_{3}\right)$. Indeed, in the CCRs, the quartz $\left(\mathrm{SiO}_{2}\right)$, the aluminosilicate (gehlenite or $\left.\mathrm{Ca}_{2} \mathrm{Al}_{2} \mathrm{SiO}_{7}\right)$ and hematite $\left(\mathrm{Fe}_{2} \mathrm{O}_{3}\right)$ represent the principal constituents, which influence the concentration of alumina, silica and iron oxides (about 87\%) [4].

The content raised in $\mathrm{SiO}_{2}(35 \%), \mathrm{Al}_{2} \mathrm{O}_{3}(70 \%), \mathrm{MgO}(5 \%), \mathrm{SiO}_{3}(2,75 \%)$ and $\mathrm{Na}_{2} \mathrm{O}(1,5 \%)$ in the CCRs, is favorable to its use as Portland pozzolana cement. Table IV presents a summary of the different chemical elements in the combustion residues of an India plant. The toxic substances detectable in the bottom ash are: the arsenic, the mercury, the iron, the chromium, the cadmium, the selenium and the nickel. They are considered potentially dangerous when we found them in very elevated proportions. 
TABLE IV Summary of chemical parameters of BA plant in India [4]

\begin{tabular}{|c|c|c|}
\hline \multicolumn{3}{|c|}{ Chemical properties of typical Indian CCRs } \\
\hline Sl. no. & Parameters & Indian CCRs \\
\hline \multicolumn{3}{|c|}{ Range (\%) } \\
\hline 1 & Aluminum $(\mathrm{Al})$ & $15,167-20,45$ \\
\hline 2 & Calcium $(\mathrm{Ca})$ & $0,37-0,76$ \\
\hline 3 & Iron $(\mathrm{Fe})$ & $4,447-6,562$ \\
\hline 4 & Manganese (Mn) & $0,002-0,84$ \\
\hline 5 & Magnesium (Mg) & $0,02-0,9$ \\
\hline 6 & Phosphorous (P) & $0,06-0,3$ \\
\hline 7 & Potassium $(\mathrm{K})$ & $0,14-1,8$ \\
\hline 8 & Silicon (Si) & $27,413-29,554$ \\
\hline 9 & Sodium $(\mathrm{Na})$ & $0,07-0,71$ \\
\hline 10 & Sulphur (S) & $0,03-0,055$ \\
\hline \multicolumn{3}{|c|}{ Range (ppm) } \\
\hline 11 & Arsenic (As) & $5-68$ \\
\hline 12 & Barium (Ba) & $26-1275$ \\
\hline 13 & Boron (B) & $100-1000$ \\
\hline 14 & Cadmium $(\mathrm{Cd})$ & $1-26$ \\
\hline 15 & Chromium (Cr) & $10-353$ \\
\hline 16 & Copper $(\mathrm{Cu})$ & $39-1000$ \\
\hline 17 & Cobalt (Co) & $7-128$ \\
\hline 18 & Lead $(\mathrm{Pb})$ & $10-144$ \\
\hline 19 & Nickel (Ni) & $29-265$ \\
\hline 20 & Mercury (Hg) & $0-0,005$ \\
\hline 21 & Molybdenum (Mo) & $8-100$ \\
\hline 22 & Scandium (Sc) & $0,5-106$ \\
\hline 23 & Selenium (Se) & $1-10$ \\
\hline 24 & Vanadium (V) & $40-190$ \\
\hline 25 & Zinc $(\mathrm{Zn})$ & $10-250$ \\
\hline
\end{tabular}

VIII. THE POZZOLANIC PROPERTIES OF THE MINERAL COAL COMBUSTION RESIDUES

In the cements ASTM standard [34], the pozzolana are defined like the siliceous materials or aluminosilicate witch doesn't possess in themselves binding properties but that react chemically, in finely divided form and in the presence of moisture, with the calcium hydroxide at ordinary temperature to form compounds having binding properties. According to the standard [36], a material has the characteristic of a pozzolana if:

- Its chemical composition checks: $\mathbf{A L}_{2} \mathbf{O}_{3}+\mathbf{S i O}_{2}+\mathbf{F e}_{2} \mathbf{O}_{3}>\mathbf{7 0} \%$

- Its activity indication $\mathbf{I}$ is: $\mathbf{0 , 6 7}<\mathbf{I}<\mathbf{1}$.

Thus, based on the chemical composition of the CCRs, we can associate them a pozzolanic character. However few studies have been led on the potential pozzolanic properties of the bottom ash. In terms of the CCRs, the studies on the pozzolanicity, were more concerned the fly ash because they have the advantage to have a fine granulometry as the one of the cement. Nevertheless, since $1999 \mathrm{M}$. Cheriaf and some studies are also led on the potential use of the bottom ash as additive in the cement [35]. On the Brazilian CCRs, it is found that the bottom ash has a pozzolanic reactivity (of $88 \%$ in 28 days) permitting its use as additive in the Portland cement production. H. Kurama and al, also show that while substituting the cement by $15 \%$ of bottom ash, an increase of the resistances to bending and to the compression of the mortars is observed after 56 days of cure [36].

\section{IX.RESULTS AND DISCUSSION}

\section{A. Physical and chemical characterization of the solid residues of TPP}

The International ASTM (American Society for Testing and Material), is an organism of normalization that writes and produces the technical standards concerning the materials, the products, the systems and the services. It has been founded in 1898 in the United States under the direction of Charles Benjamin Dudley. Its founders were scientists and engineers. Its creator wanted to reduce the number of ruptures of railroad rails that often arrived in this industry in full growth. The group developed a standard concerning steel used for the rails manufacture.

Today, international ASTM has more than 12000 standards in its catalog. The yearly publication of the ASTM standards book is composed of seventy-seven volumes. 
The association members are the representatives of the industrial, the users, the governments and the universities of more than hundred countries [37].

TABLE V Chemical composition of the sample studied.

\begin{tabular}{|c|c|c|c|}
\hline Components & $\%$ & According to standard & References \\
\hline Silicon dioxide $\mathrm{SiO}_{2}$ & 50,34 & ASTM D6349 & \multirow{10}{*}{ [38] } \\
\hline Aluminum oxide $\mathrm{Al}_{2} \mathrm{O}_{3}$ & 26,54 & ASTM D6349 & \\
\hline Iron oxide $\mathrm{Fe}_{2} \mathrm{O}_{3}$ & 12,87 & ASTM D6349 & \\
\hline Calcium oxide $\mathrm{CaO}$ & 0,87 & ASTM D6349 & \\
\hline Magnesium oxide $\mathrm{MgO}$ & 0,05 & ASTM D6349 & \\
\hline Sodium oxide $\mathrm{Na}_{2} \mathrm{O}$ & 2,18 & ASTM D6349 & \\
\hline Potassium oxide & 1,40 & ASTM D6349 & \\
\hline Manganese oxide $\mathrm{MnO}_{2}$ & 1,16 & ASTM D6349 & \\
\hline Titanium oxide $\mathrm{TiO}_{2}$ & 3,04 & ASTM D6349 & \\
\hline Phosphorus pentoxide & 0,14 & ASTM D6349 & \\
\hline Sulfur trioxide $\mathrm{SO}_{3}$ & 1,41 & ASTM D5016 & [39] \\
\hline
\end{tabular}

Chemical composition of the CCRs:

The chemical composition of the sample is given by the following analyses:

According to the standard ASTM [40], the fly ash present themselves in two classes:

- C class

- F class

The only difference between the two classes is the percentage of calcium oxide. For the $\mathrm{C}$ class the percentage of calcium oxide is $>20 \%$.

For our sample the calcium content is low $(<1 \%)$, therefore it is fly ash of $\mathrm{F}$ class

\section{B. Physical characteristics of CCRs}

1) Experimental calculation of total humidity: It is about taking a sample of the by-product whose mass is known and to dry it in an oven during 24 hours then calculate the new mass, by the following formula:

$$
\text { Humidity = (1 - } \left.\mathbf{M}_{\text {final }} / \mathbf{M}_{\text {initial }}\right) \times 100
$$

Results obtained: humidity of sample $=2.5 \%$

2) Experimental calculation of Loss on Ignition ratio: It is about heating a dry sample of known mass to $750^{\circ} \mathrm{C}$ during 3 hours and to measure the new mass after leaving the oven.

The calculation of the percentage of the unburned consists in first place to calculate the percentage of the organic matter, so it is given by the following formula:

$$
\text { Loss on ignition }(\%)=(\mathrm{A} / \mathrm{B}) \times 100
$$

Where:

A: loss in mass between 105 and $750{ }^{\circ} \mathrm{C}\left(221\right.$ and $\left.1382^{\circ} \mathrm{F}\right)$,

B: mass of moisture-free sample used.

Results obtained: $\quad$ LOI $=10 \%$

3) Fineness test: The principle is to use a sieve of 45 micrometer to filter a quantity of the sample and then measuring the mass retained by the sieve.

Results obtained: $76 \%$ of the particles have a fineness lower to $45 \mu \mathrm{m}$.

4) Calculation of the density: The real density of the by-product is the weight by volume unit of the sample in very fine powder. To determine the real density, the sample is dispersed in the water. The quantity of water dispersed by gram of the fly ash gives the true density of them. This density, which varies from $2 \mathrm{~g} / \mathrm{cm}^{3}$ to 2,8 $\mathrm{g} / \mathrm{cm}^{3}$, determines the volume that it must occupy for a given mass. Changes in density can indicate a source of different coal.

The procedure is to take a pot of measuring graduated in ml, clean thoroughly with pure water. Take some water in the ball until a certain level and note its level (first reading). Deposit slowly 20 grams of the sample provided in the jar. Shake the jar during a certain time. Note eater's level in the jar (final reading). Repeat this operation for 4 samples or more and compile the results. Divide the difference of the final and initial value in weight of the sample to obtain the real density. 
Results obtained: Density $=2.3 \mathrm{~g} / \mathrm{cm}^{3}$

C. Verification of compatibility with the standard ASTM C618

1) Requirements of the standard: Our sample must satisfy the requirements defined in the ASTM standard C 618 , these requirements are:

- The percentage of the organic matter for the $\mathrm{F}$ class, $\mathrm{LOI}<6 \%$;

- The percentage of (silicon oxide + aluminum oxide + iron oxide) $>70 \%$;

- The percentage of sulfur trioxide $<1.5 \%$;

- The total humidity $<3 \%$;

- The percentage of particles, less than $45 \mu \mathrm{m}$ in diameter, must be $>75 \%$.

2) Verification of the compatibility of our sample: According to the Table $\mathrm{V}$ of the analyses, the sum of the percentages of the three components (the silicon oxide $\left(\mathrm{SiO}_{2}\right)$, the aluminum oxide $\left(\mathrm{Al}_{2} \mathrm{O}_{3}\right)$ and the iron oxide $\left(\mathrm{Fe}_{2} \mathrm{O}_{3}\right)$ ) is equal to:

$$
50.34+26.54+12.87=\mathbf{8 9 . 7 5 \%} \quad(>70 \%)
$$

The percentage of sulfur trioxide $\left(\mathrm{SO}_{3}\right)$ in our sample is: $1.41 \%(<1.5 \%)$;

- The total humidity of our sample is: $\mathbf{2 . 5 \%}$ ( $<3 \%$ definite in the Standard);

- The Loss on Ignition ratio of the sample is: $\mathbf{1 0 \%}$ ( $>6 \%$ definite in the Standard), that means that our material contains a high percentage of the organic matter. In most cases, this problem is therefore due to a defect in the boiler, so a maintenance is essential for an energy reason (unburned $=$ lost energy) and also to have a residue recoverable without risks. Fortunately, the standard tolerates a percentage until $12 \%$ under the condition to verify with physical tests the security of the concrete.

\section{Economic Concrete Manufacturing}

This experience consists to manufacture some samples made from CCRs, cement and water. After the coherence of the components, they are left to harden at the ambient temperature, then to characterize them by mechanical tests.

We have prepared mixtures of cement and CCRs by varying the percentage of every component each time. For the sample composed of $10 \%$ CCRs and $90 \%$ cement, and the sample composed of $60 \%$ CCRs and $40 \%$ cement; we have added to each two different quantities of water, a maximum quantity and other minimal in order to study the influence of water on the mixture. We obtained 8 samples, see Table VI. We put the mixtures into cubic molds having an edge of $10 \mathrm{~cm}$, Fig. 9.

TABLE VI Details of the eight samples studied

\begin{tabular}{|l|l|l|l|}
\hline \multirow{2}{*}{ Sample } & \multicolumn{2}{|c|}{ The mixture (CCRs + Cement) } & \multirow{2}{*}{$\begin{array}{c}\text { The report } \\
\text { Water/Mixture }\end{array}$} \\
\cline { 2 - 3 } & The quantity of CCRs & The quantity of Cement & Min \\
\hline 1 & $10 \%$ & $90 \%$ & Max \\
\hline 2 & $10 \%$ & $90 \%$ & - \\
\hline 3 & $20 \%$ & $80 \%$ & - \\
\hline 4 & $30 \%$ & $70 \%$ & - \\
\hline 5 & $40 \%$ & $60 \%$ & - \\
\hline 6 & $50 \%$ & $50 \%$ & Min \\
\hline 7 & $60 \%$ & $40 \%$ & Max \\
\hline 8 & $60 \%$ & $40 \%$ & \\
\hline
\end{tabular}
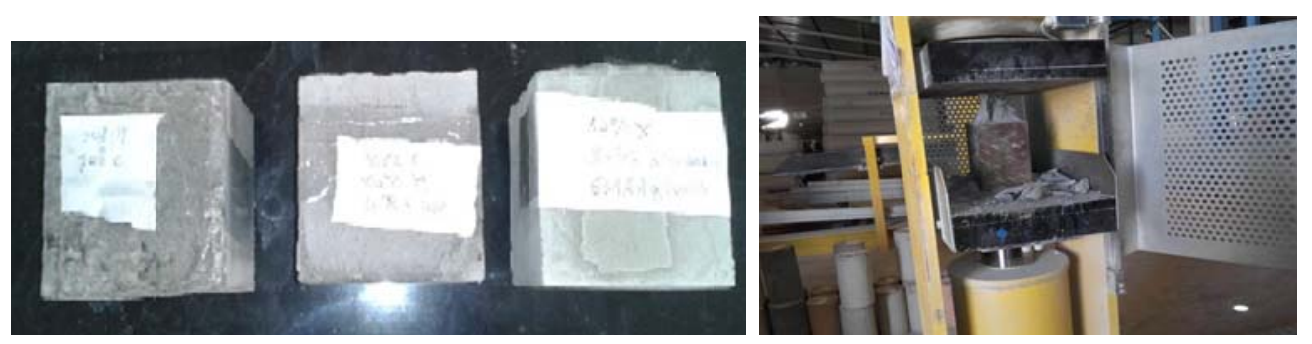

Fig. 9. Samples studied and the compression machine. 
TABLE VII Results of mechanical testing

\begin{tabular}{|l|l|l|l|l|}
\hline Samples & CCRs & Cement & Report Water/Mixture & Compression (MPa) \\
\hline E1 & $10 \%$ & $90 \%$ & Max & 22.2 \\
\hline E2 & $10 \%$ & $90 \%$ & Min & 24.20 \\
\hline E3 & $20 \%$ & $80 \%$ & - & 16.87 \\
\hline E4 & $30 \%$ & $70 \%$ & - & 13.00 \\
\hline E5 & $40 \%$ & $60 \%$ & - & 10.2 \\
\hline E6 & $50 \%$ & $50 \%$ & - & 10 \\
\hline E7 & $60 \%$ & $40 \%$ & Max & 5.9 \\
\hline E8 & $60 \%$ & $40 \%$ & Min & 5.8 \\
\hline
\end{tabular}

After the constraints encountered in the first experiment where we chose the temperature as a second factor instead of water, we found that varying the temperature of the mixture (cement / CCRs) we will destroy the internal structure of the latter, as shown in Fig. 10-(b). In the second experiment we determined the exact percentages of CCRs and cement of the best performing sample, where we will integrate it in the third experiment having the objective to manufacture a brick of the clay with our adequate mixture of cement and CCRs having a good result (being between the E2 sample and E3), that means; to take between $10 \%$ to $20 \%$ of CCRs and between $80 \%$ to $90 \%$ of the cement, thus we choose the water as the dosage parameter, as shown in Table VII and Fig. 9.

We have two factors:

- The first factor is the quantity of CCRs;

- The second factor is report water / mixture, where the mixture is constituted of cement and CCRs.

(a)

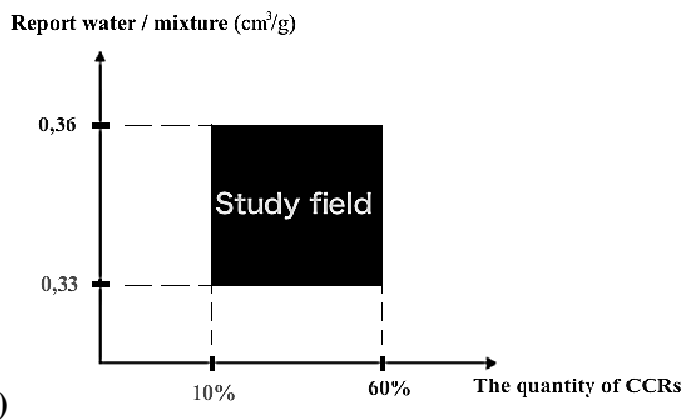

(b)

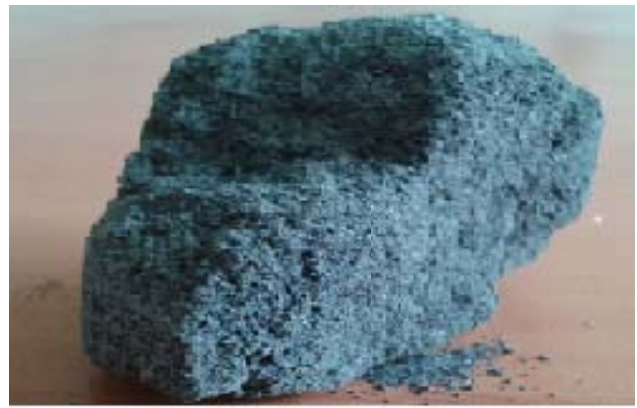

Fig. 10. The chosen experience plan (a), the new form of the sample (non-homogeneous structure) after the integration of the temperature factor in this study (b).

The high levels and the low levels of all factors define the study field, Fig. 10-(a). In our case, for the first factor (the quantity of CCRs) its low level is equal to $10 \%$ and its high level is equal to $60 \%$. For the second factor (The report water/mixture) its low level is 0.33 and its high level is 0.36 , therefore the domain of study of the first factor will be $[10 \%, 60 \%]$ and for the second factor, we will have $[0.33,0.36]$.

We can gather the high and low levels of the two factors in the Table VIII.

TABLE VIII The high and low levels of selected factors.

\begin{tabular}{|l|l|l|}
\hline Factors & Low level & High level \\
\hline Quantity of CCRs & $10 \%$ & $60 \%$ \\
\hline Report water/Mixture & 0.33 & 0.36 \\
\hline
\end{tabular}

\section{E. The experimental point}

The level $35 \%$ of the CCRs and the level 0.345 of the report water/mixture can be considered as the coordinates of one point of the experimental space; a given experience is represented therefore, in the Fig. 11, by one point. 


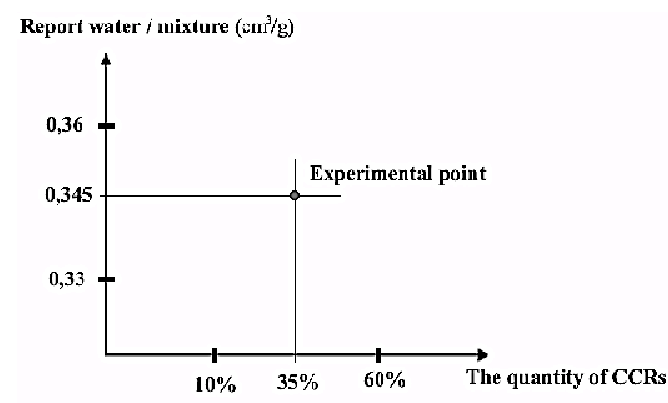

Fig. 11. The choice of an experimental point.

The choice of the number of the experiment point's location is the fundamental problem of the experimental plans. We are trying to achieve the minimum of experiences while looking for the solution to the problem posed. Therefore we want to do the least possible tests; the best choice of the experiences is to take the points whose coordinates are the high levels and the low levels. In our case, we will choose the points witch are located in the summits of the study field, so we could take the four points, but it is possible to add a supplementary point located at the center of the study domain that will serve the creation of one control point.

This type of plan is called a complete factorial plan, we note $\mathbf{2}^{2}$. The interest of the coded units is to be able to present the experiences plans in the same way whatever the study fields selected and the factors. The compression results are presented in Table IX.

TABLE IX Test results of the $1^{\text {st }}$ experimental plan.

\begin{tabular}{|l|l|l|l|}
\hline Samples & CCRs & Report water/mixture & Solution (in MPa) \\
\hline E1 & $10 \%$ & 0.33 & $\mathrm{Y}_{1}=24.2$ \\
\hline E2 & $60 \%$ & 0.33 & $\mathrm{Y}_{2}=5.8$ \\
\hline E3 & $10 \%$ & 0.36 & $\mathrm{Y}_{3}=22.2$ \\
\hline E4 & $60 \%$ & 0.36 & $\mathrm{Y}_{4}=5.9$ \\
\hline
\end{tabular}

\section{F. The mathematical modelling}

We can represent the function that binds the response to the factors by a general expression in the following form:

$$
Y=a_{0}+a_{1} \cdot x_{1}+a_{2} \cdot x_{2}+\cdots+a_{n} \cdot x_{n} \mid+\sum_{i, j=1}^{n} a_{i \neq j} \cdot x_{i} \cdot x_{j}+\sum_{i, j, k=1}^{n} a_{i \neq j \neq k} \cdot x_{i} \cdot x_{j} \cdot x_{k}+\cdots
$$

Since we have two factors, then this function becomes in the following form:

$$
\mathbf{Y}=\mathbf{a}_{0}+\mathbf{a}_{1} \mathbf{x}_{1}+\mathbf{a}_{2} \mathbf{x}_{2}+\mathbf{a}_{12} \mathbf{x}_{1} \mathbf{x}_{2}
$$

With:

- $\mathbf{Y}$ : is the response in the point of the chosen composition;

- $\quad \mathbf{x}_{1}, \mathbf{x}_{2}$ : are the respective contents of cement and CCRs;

- $\mathbf{a}_{0}, \mathbf{a}_{1}, \mathbf{a}_{2}$ : are the unknown coefficients.

If the responses and the factors are known, we pass to determine the coefficients.

Therefore we find that:

$$
\begin{aligned}
& Y_{1}=a_{0}-a_{1}-a_{2}+a_{12} \\
& Y_{2}=a_{0}+a_{1}-a_{2}-a_{12} \\
& Y_{3}=a_{0}+a_{1}-a_{2}+a_{12} \\
& Y_{4}=a_{0}+a_{1}+a_{2}+a_{12}
\end{aligned}
$$

Hence the mathematical model becomes:

$$
Y=14.525-8.675 x_{1}-0.475 x_{2}+0.525 x_{1} x_{2}
$$

This model allows calculating all the responses in the study field; it is sufficient to assign values to the levels $\mathrm{x}_{1}$ and $\mathrm{x}_{2}$ to obtain immediately the best value of the adequate response.

The experimental plan serves to optimize the number of experiments to be realized and to determine the mixing model that lets to calculate all the responses in the study field of without experiencing, it is enough to attribute values to cement and CCRs contents to immediately obtain the value of the response. In our case, it can 
be seen from the results obtained from the compression test that the sample which is more resistant is the sample of $10 \%$ of CCRs and 0.33 water / mixture report.

\section{G. The final experimental plan}

We have prepared mixtures of $1740 \mathrm{~g}$. They are comprised of clay and the product "E1" which is the most effective of cement and CCRs mixture and we will vary the percentage of each component. For the sample composed of $50 \%$ of clay and $50 \%$ of the product E1 and the sample composed of $80 \%$ of clay and $20 \%$ of the product E1, we added to each two different quantities of water; one maximum and another minimum quantity in order to study the influence of water on the mixture. We obtained four samples illustrated in Table X.

TABLE X Test results of the $1^{\text {st }}$ experimental plan.

\begin{tabular}{|c|c|c|c|}
\hline \multirow{2}{*}{ Samples } & \multicolumn{2}{|c|}{ The mixture (Clay, Product E1) } & \multirow{2}{*}{$\begin{array}{c}\text { The water } \\
\text { volume } \mathbf{( c m}^{3} \text { ) }\end{array}$} \\
\cline { 2 - 3 } & The quantity of Clay & The quantity of Product E1 & 581 \\
\hline 1 & $50 \%$ & $50 \%$ & 581 \\
\hline 2 & $80 \%$ & $50 \%$ & 633 \\
\hline 3 & $50 \%$ & $20 \%$ & 633 \\
\hline 4 & $80 \%$ & $20 \%$ & \\
\hline
\end{tabular}

We let them dry at ambient temperature and then we put them in an oven at a temperature between $700{ }^{\circ} \mathrm{C}$ and $800^{\circ} \mathrm{C}$, after this operation we are getting the fired bricks as shown in Fig. 12.

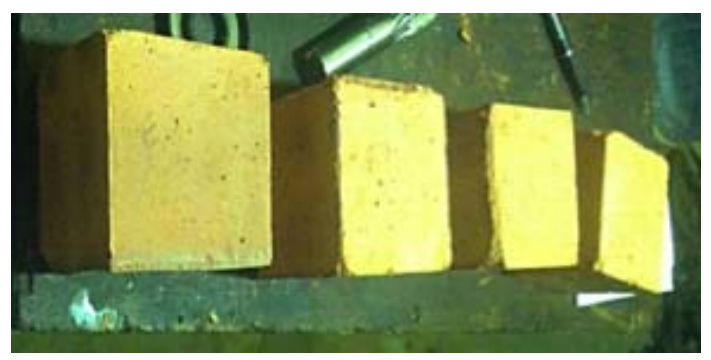

Fig. 12. The four samples after firing

After applying mechanical compression test on the four samples, the following results were obtained in the Table XI.

Due to integrate the humidity as a parameter in our analysis, we measure the weight of the bricks before and after firing, see Table XII.

TABLE XI Mechanical compression test results.

\begin{tabular}{|c|c|c|c|}
\hline Samples & Clay & $\begin{array}{l}\text { The water volume } \\
\left(\mathrm{cm}^{3}\right)\end{array}$ & $\begin{array}{l}\text { The compressive } \\
\text { strength (MPa) }\end{array}$ \\
\hline E1 & $50 \%$ & 581 & 3.12 \\
\hline E2 & $80 \%$ & 581 & 3.02 \\
\hline E3 & $50 \%$ & 633 & 2.65 \\
\hline E4 & $80 \%$ & 633 & 2.44 \\
\hline
\end{tabular}

The goal is to build an economical brick built by the first mixture (CCRs + Cement) and Clay, this brick must be resistant. Then we have to determine the exact percentage of $1^{\text {st }}$ mixture which is already determined in the first study and which consists of $10 \%$ CCRs and $90 \%$ cement as well as the percentage of clay; the main component of this brick.

TABLE XII Weight of the bricks before and after firing

\begin{tabular}{|c|c|c|c|}
\hline Samples & Weight after (Kg) & Weight before (Kg) & Dimension \\
\hline E1 & 1.181 & 1.780 & $9.6 \mathrm{~cm}$ \\
\hline E2 & 1.173 & 1.790 & $10 \mathrm{~cm}$ \\
\hline E3 & 1.150 & 1.720 & $9.8 \mathrm{~cm}$ \\
\hline E4 & 1.091 & 1.750 & $9.8 \mathrm{~cm}$ \\
\hline
\end{tabular}

The response of our study is the mechanical characteristic of the bricks from the compression tests that we will do on the samples. There are two factors:

- The first factor is the quantity of the clay; 
- The second factor is the volume of water.

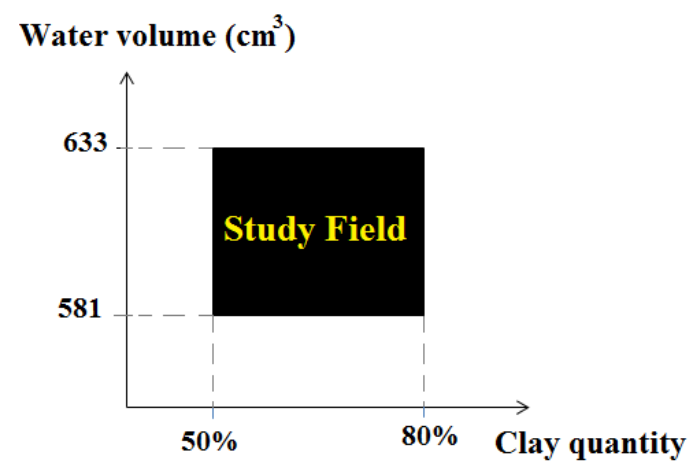

Fig. 13. The $2^{\text {nd }}$ experience plan of our study

For the $1^{\text {st }}$ factor (the clay quantity), the low level is equal to $50 \%$ and the high level is equal to $80 \%$, and for the $2^{\text {nd }}$ factor (the water volume), the low level is 581 and the high level is 633 , the study field of $1^{\text {st }}$ factor is therefore $[50 \%, 80 \%]$ and for $2^{\text {nd }}$ factor we have [581, 633], as shown in Fig. 13.

The field of study is made up of all points whose coordinates are inside the areas of each factor. We will perform an experience plan of two factors where we involve four experiments, see Table XIII.

TABLE XIII Our experience plan with the four experiments.

\begin{tabular}{|c|c|c|}
\hline Test & The clay quantity & The water volume $\mathbf{( c m}^{\mathbf{3}} \mathbf{)}$ \\
\hline 1 & $50 \%$ & 581 \\
\hline 2 & $80 \%$ & 581 \\
\hline 3 & $50 \%$ & 633 \\
\hline 4 & $80 \%$ & 633 \\
\hline
\end{tabular}

After the completion of the mechanical compression tests, we have obtained the results in the Table XIV and the mean curve of compressive strength in Fig. 14.

TABLE XIV Results of the mechanical compression tests

\begin{tabular}{|c|c|c|c|}
\hline Samples & Clay quantity & Water volume $\mathbf{( c m}^{\mathbf{3}} \mathbf{)}$ & Response (MPa) \\
\hline E1 & $50 \%$ & 581 & 3.12 \\
\hline E2 & $80 \%$ & 581 & 3.02 \\
\hline E3 & $50 \%$ & 633 & 2.65 \\
\hline E4 & $80 \%$ & 633 & 2.44 \\
\hline
\end{tabular}

In the same way carried out in the previous experiment plan, our mathematical model becomes as the following:

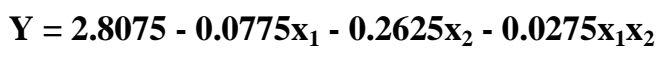

At the center of the domain, the compressive strength is $2.8075 \mathrm{MPa}$, see Fig. 14.In fact, the effect of the clay quantity is -0.0775 ; That means a negative effect, in other words, when the quantity of clay passes from the central point of the study field ( $65 \%$ clay and $607 \mathrm{~cm} 3$ of water) to point $\mathrm{G}$, the compressive strength decreases. Thus, when the clay quantity passes from point $\mathrm{O}$ to point $\mathrm{F}$, the compressive strength increases, as shown in Fig. 15. 


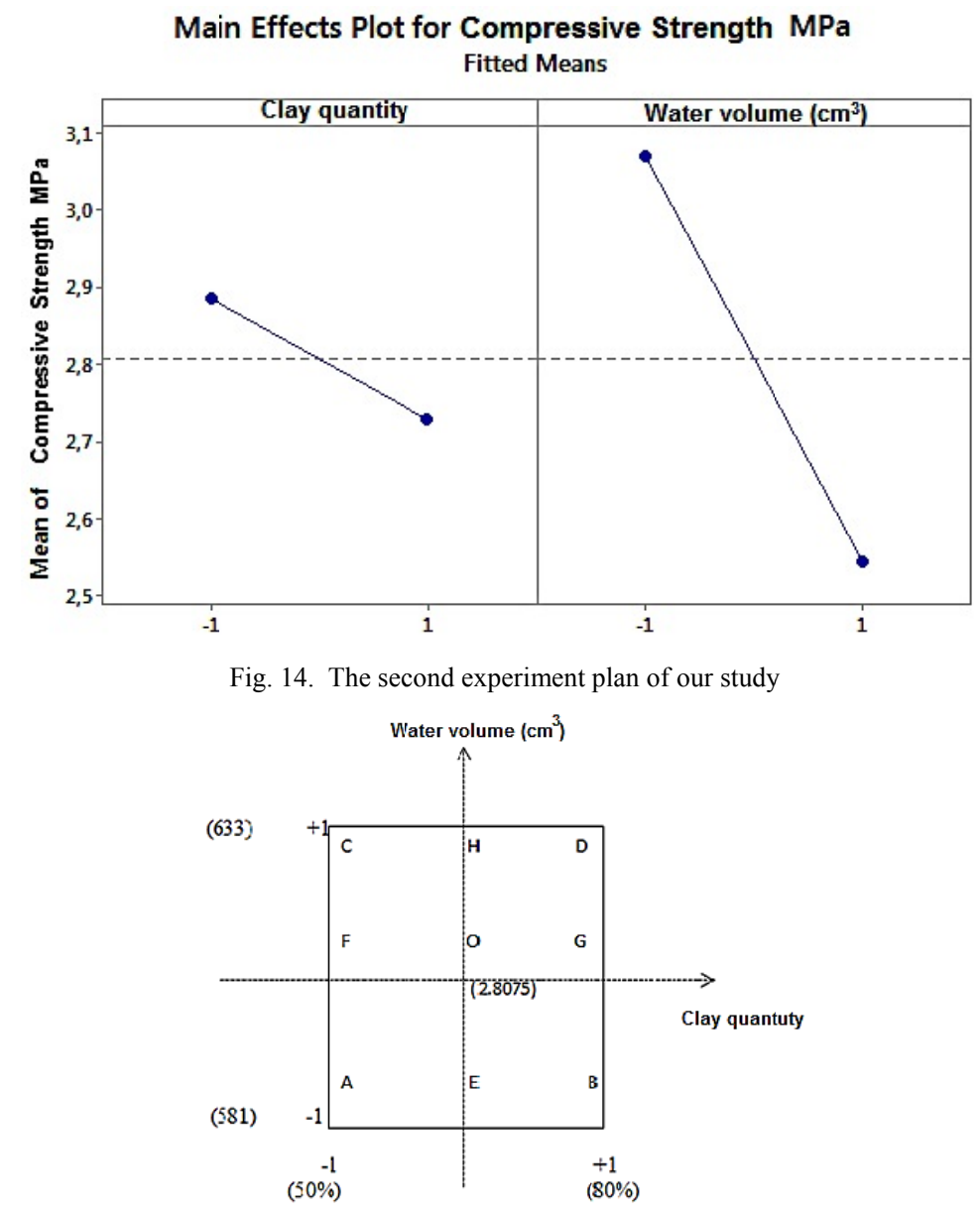

Fig. 15. Centralization of the study field.

We have verified the interaction curve between the two factors, as shown in Fig. 16 and we have found that the lines are almost parallel; we deduce that there is no interaction between the clay quantity and the water volume. The volume of water increases the effect of the quantity of clay. Then, to get an important resistance to compression, it must to have a maximum of $50 \%$ of the quantity of clay and $578 \mathrm{~cm}^{3}$ of water.

But, the problem encountered in this analysis step was to decide: what is the most important factor to be brought out (critical factor between the two used in this $2^{\text {nd }}$ experimental plan) in the bricks manufacture based on CCRs, Cement and clay?

In other words, we are obliged to study the significance of each factor in our plan. For this purpose we use the Parito Diagram illustrated in Fig. 17, we can see that the factor $\mathbf{B}$ (the volume of water) is significant in relation to the factors: A (the quantity of clay) and the combination possible $\mathbf{A B}$ between the two factors, according to the statistical point of view (as it's according to the measures put in our own experience).

Finally, we can now optimize the response of our model after the validation of this second experiment plan, which was constituted on the basis of four tests only, as shown in Fig. 18, where the maximum response that we can have it is 3,12 MPa.

This experiment allows us to determine the exact responses of the clay and the product E1 (contains $10 \%$ CCRs and $90 \%$ Cement), thus studying the influence of water on the compressive strength of bricks. 


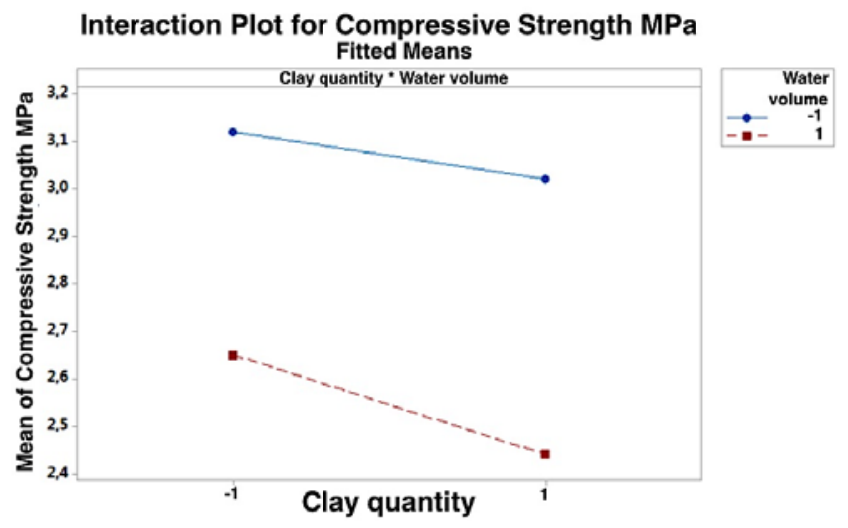

Fig. 16. The interaction curve for the compressive strength.

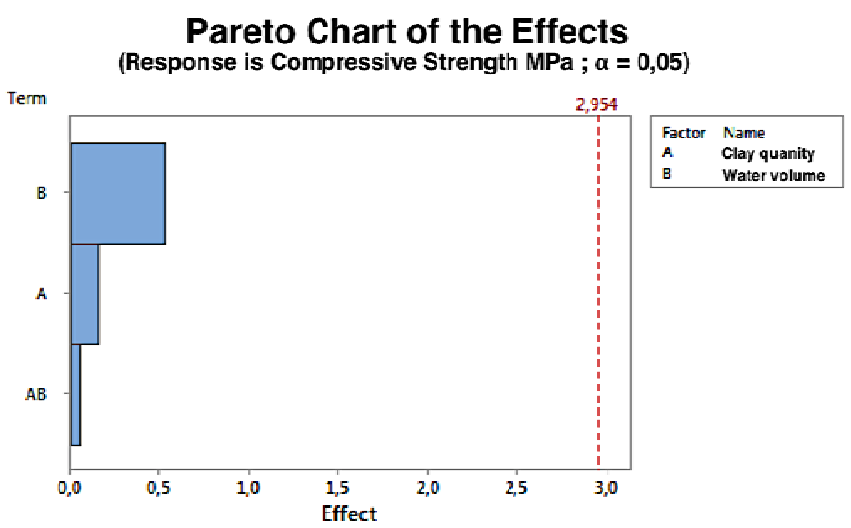

Fig. 17. The significance study of the factors by Pareto Diagram.

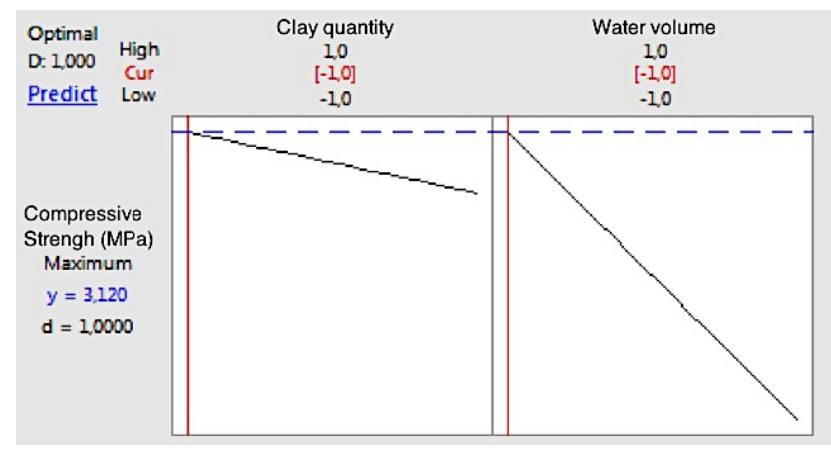

Fig. 18. Optimization Plot of the $2^{\text {nd }}$ experiment plan.

\section{CONClusion}

This study contributes to the CCRs valorization, as in [4], [11], [12], [13]-[22], by its exploitation in the manufacture of the bricks, as in [4], [14], [15], [16] and [22]. We have chosen the last five works as basic references by the fact to analyze the results found in these researches on FA only and applying them on all CCRs (i.e., on BA and FA in one mixture) by a new method which is the experimental plans [41]. However, in the first experiment, we've reached our goal that is to construct a resistant material to the compression, after verification of the requirements of the ASTM standard, on the basis of $10 \%$ CCRs and of $90 \%$ cement with a report water/mixture of 0.33 in volume.

While in the last experiment performed, we constructed the fired bricks on the basis of the clay and the material constructed in the first experiment, we found that the most resistant bricks were those in which we used a minimum volume of water $581 \mathrm{~cm}^{3}$ and a minimum amount of clay $50 \%$.

The experiments have been carried out with the help of the experiences plans method, which have been useful to optimize the number of experiments to carry out, as well to determine the amount to use of each component and analyze the effect of each factor on the response.

Finally, we remind that the main issue of this work is the reducing the environmental impact of this waste and the research of a practical solution to reuse them in the bricks and concrete manufacture. 


\section{ACKNOWLEDGMENTS}

The authors are pleased to acknowledge the University of Mons in Belgium to provide the facilities for research. In addition, the Director of Jerada thermal power plant (ONEE) Morocco and the Director of The ARGILUX brick factory of the city Oujda Morocco. We thank for his kind permission to use their laboratories for this works.

\section{REFERENCES}

[1] European Agency for the environment, “An Assessment of Assessments, report on the state of the Europe's environment", in Proc. EEA'11, 2011, paper 10.2800/78360, p. 103.

[2] J. Fu, "Challenges to Increased Use of Coal Combustion Products in China", Master's Program. Energy and Environmental Engineering, Department of Management and Engineering, Lingkopings Universitet, dissertation thesis, ISRN-LIU-IEI-TEK-A10/00853-SE, Spring 2010.

[3] R. Vinai, A. Lawane, J.R. Minane and A. Amadou, "Coal combustion residues valorization: Research and development on compressed brick production", Constr Build Mater, Vol. 40, pp. 1088-1096, 2013.

[4] American Coal Ash Association. (2015) ACAA-Publications webpage on ACAA-USA. [Online]. Available: https://www.acaausa.org/Publications/Production-Use-Reports/

[5] P. Asokan, M. Saxena and SR. Asolekar, "Coal combustion residues - environmental implications and recycling potentials", Resources, Conservation and Recycling, Vol. 43, pp. 239-62, 2005.

[6] European Coal Combustion Products Association. (2010) ECOBA-EU-15 webpage on ECOBA. [Online]. Available: http://www.ecoba.com/ecobaccpprod.html/

[7] (2015) The Ash Development Association of Australia (ADAA) website. [Online]. Available: http://www.adaa.asn.au/

[8] (2012) Japan Coal Energy Center (JCOAL) website. [Online]. Available: http://www.jcoal.or.jp/eng/

[9] Association of Canadian Industries Recycling Coal Ash - CIRCA. (2013) World of coal Ash WOCA'13 Conference webpage on FLYASH. [Online]. Available: http://www.flyash.info/2013/119-Weir-2013.pdf

[10] Vivian W.Y. Tama and C.M. Tam, "A review on the viable technology for construction waste recycling", Resour Conserv Recy, Vol 47 (3), p. 209-221, 2006.

[11] A. Ohnaka, T. Hongo, M. Ohta and Y.Izumo. (2005) World of coal Ash WOCA'05 Conference webpage on FLYASH. [Online]. Available: http://www.flyash.info/2005/179ohn.pdf

[12] H. Liu, S.K. Banerji, W.J. Burkett and J. VanEgelenhoven. (2009) World of coal Ash WOCA'09 Conference webpage on FLYASH. [Online]. Available: http://www.flyash.info/2009/140-liu2009.pdf

[13] O. Kayali. (2005) World of coal Ash WOCA'05 Conference webpage on FLYASH. [Online]. Available: http://www.flyash.info/2005/5kay.pdf

[14] M. Chou and F. Botha. (2003) International Caol Ash Utilization Symposium ICAUS'03 Conference webpage on FLYASH. [Online]. Available: http://www.flyash.info/2003/25cho.pdf

[15] Y-S. Hsu, B-J. Lee and H. Liu. (2003) International Caol Ash Utilization Symposium ICAUS'03 Conference webpage on FLYASH. [Online]. Available: http://www.flyash.info/2003/89hsu.pdf

[16] T. Fatih and A. Ümit. (2001) International Ash Utilization Symposium IAUS'03 Conference webpage on FLYASH. [Online]. Available: http://www.flyash.info/2001/conprod2/13atlay.pdf

[17] V. G. Lemeshev, I. K. Gubin, Yu. A. Savel'ev and D. V. Tumanov, "Lemeshev DO. Utilization of coal-mining waste in the production of building ceramic materials", Glass and Ceramics, Vol. 61, pp. 308-311, Sep 2004.

[18] L. Haibin, L. Zhenling, "Recycling utilization patterns of coal mining waste in China", Resour Conserv Recy, Vol. 54, pp. 1331-1340, 2010.

[19] B. A. Dockter, K. E. Eylands and L. L. Hamre. (1999) International Ash Utilization Symposium IAUS'99 Conference webpage on FLYASH. [Online]. Available: http://www.flyash.info/1999/construc/pflug22.pdf

[20] J. Rogbeck, A. Knutz, "Coal bottom ash as light fill material in construction", Waste Management, Vol. 16 (1-3), pp. 125-8, Dec 1996.

[21] M. Anieto, A. Acosta, J. M. Rincon and M. Romero. (2005) World of coal Ash WOCA'05 Conference webpage on FLYASH. [Online]. Available: http://www.flyash.info/2005/7ain.pdf

[22] R. Meij, E. Kokmeijer, L. Tamboer and H. te Winkel. (2001) International Ash Utilization Symposium IAUS'01 Conference webpage on FLYASH. [Online]. Available: http://www.flyash.info/2001/conprod3/97meij.pdf

[23] R. Siddique, "Utilization of coal combustion by-products in sustainable construction materials", Resour Conserv Recy, Vol. 54 Iss 12 , pp. 1060-1066, 2010.

[24] J. B. Leroy, Waste and its treatment, 1st ed, Collection what do I know, PUF, Ed. Paris, France: University Press of France, 1994.

[25] S. Galaup, C. Baudoin, "Industrial waste law and policy comparative analysis of six national strategies in Europe", Waste Science and Technology, Vol.1, pp. 4-8, 1996.

[26] C. London, "The legal notion of waste or some semantic questions", Waste Science and Technology, Vol.1, pp. 8-10, 1996.

[27] B. Debray, "Decision support systems for the treatment of special industrial wastes", Civil. Mines. Eng thesis, Lyon National Institute of Applied Sciences, Lyon, France, July 1997.

[28] L.Y. Maystre and F. Viret, “A goal-oriented characterization of urban waste”, Waste Management \& Research, Vol. 13, pp. 207-218, 1995.

[29] D. Tyteca, "On the Measurement of the Environmental Performance of Firms - A Literature Review and a Productive Efficiency Perspective", Journal of Environmental Management, Vol. 46, pp. 281-308, 1996.

[30] ONEE Electrical Branch, "Environmental impact assessment project for the Jerada thermal power plant extension", Jerada TPP, Clean Tech. Rep. SP94036P4, 2014.

[31] A. Stoch, "Fly ash from coal combustion - characterization", Energy Engineering and Management thesis, Instituto Superior Técnico, Lisboa, Portugal, Feb 2015.

[32] J. Rogbeck and A. Knutz, "Coal bottom ash as light fill material in construction”, Waste Management, Vol.16, pp. 125-128, 1996.

[33] P. Kishor, A.K. Ghosh and D. Kumar, "Use of Flyash in Agriculture: A Way to Improve Soil Fertility and its Productivity", Asian Journal of Agricultural Research, Vol. 4, pp. 1-14, 2010.

[34] Test methods for sampling and testing fly ash or natural pozzolans for use as a mineral admixture in Portland cement concrete, ASTM Std. C 311-02, 2009.

[35] M. Cheriaf, J.C. Rocha and J. Péra, "Pozzolanic properties of pulverized coal combustion bottom ash", Cement and Concrete Research, Vol. 29, pp. 1387-1391, Sep 1999.

[36] H. Kurama, M. Kaya, "Usage of coal combustion bottom ash in concrete mixture", Construction and Building Materials, Vol. 22, pp. 1922-1928, Sep 2008. 
[37] (2017) The ASTM website. [Online]. Available: https://www.astm.org/

[38] Test Method for Determination of Major and Minor Elements in Coal, Coke, and Solid Residues from Combustion of Coal and Coke by Inductively Coupled Plasma—Atomic Emission Spectrometry, ASTM Std. D6349, 2009.

[39] Test Method for Total Sulfur in Coal and Coke Combustion Residues Using a High-Temperature Tube Furnace Combustion Method with Infrared Absorption, ASTM Std. D5016, 2009.

[40] Specification for coal fly ash and raw or Calcined natural pozzolan for use in concrete, ASTM Std. C 618-02, 2009.

[41] J. Goupy and L. Creighton, Introduction to Experimental Plans, 3rd ed, Dunod, Ed. Malakoff Cedex, France, 2006.

\section{AUTHOR PROFILE}

YOUSSEF REGAD engineer research in industrial engineering on the theme valorization and characterization of CCRs of Jerada TPP.

BACHIR El KIHEL Professor of Higher Education Grade: C, head of department industrial engineering. $\mathrm{PhD}$ status in Structural Design. PhD University of Compiegne engineering school France in Vibration and control non-destructive.

Prof. FABIENNE DELAUNOIS Associate Professor- Head of Service Metallurgy University of Mons Belgium. 